\title{
Mechanical strength of bio-coke from briquettes
}

\author{
L. Florentino-Madiedo, E. Díaz-Faes, C. Barriocanal* \\ Instituto Nacional del Carbón, INCAR-CSIC. C/ Francisco Pintado Fe, 26. 33011 \\ Oviedo. Spain \\ *Corresponding author: carmenbr@incar.csic.es
}

\begin{abstract}
Cokes made from briquettes composed of a high volatile bituminous coal combined with four different biomasses and four different binders were analyzed in order to evaluate the influence of these materials on their mechanical strength. The results presented in this work are part of a more extensive research plan aimed at widening
\end{abstract} the range of alternative raw materials that can be included in coking blends. The briquettes were studied by means of proximate and elemental analyses and density evaluation, whereas the cokes were subjected to micro-strength, compression strength, porous characterization and quantitative evaluation of the textural composition by means of polarized light microscopy (PLM). Various parameters derived from these different techniques were used to explain the effects of biomass and binder on the strength of the coke prepared with the briquettes. Bituminous binders are the most effective because they increase Gieseler fluidity and have a lower volatile matter content than molasses and paraffin. The biomasses that gave rise to the most resistant bio-cokes were lignin and a bio-coal, derived from hydrothermally treated waste lignocellulosic biomass.

Keywords: briquettes; bio-coke; strength; biomass; binder 
Nowadays, environmental pollution is one of the main challenges facing the steel industry. $26 \%$ of global $\mathrm{CO}_{2}$ industrial emissions comes from the iron and steel industry [1]. Therefore, to ensure the growth of the steel sector, greater attention must be devoted to developing environmentally friendly processes. Another major challenge for this industry is the huge amount of raw material it consumes. The inclusion of biomass in coking blends could be a possible solution to both of these problems. Biomass has been increasingly investigated in recent years with a view to widening the range of alternative raw materials that can be included in coking blends $[1,2]$. One of the reasons for using biomass is its renewability and carbon-neutrality which translates into zero global emissions of $\mathrm{CO}_{2}$ to the atmosphere. At the same time, the addition of biomass to a coking blend has been shown to decrease coke quality when the level of addition is higher than 2 wt.\% [2]. Densification of raw materials by thermal treatment and briquetting have shown to mitigate the worsening in the quality of coke produced by blends of coal and biomass [3]. Torrefaction and hydrothermal carbonization (HTC) have been studied for its use in combustion and in the preparation of carbonaceous materials but there are hardly any published works related to its use in the steel industry. There are some studies on the direct addition of charcoal $[3,4]$ but the use of pre-treated biomass in the form of briquettes is very limited [5]. Bituminous binders commonly used to make briquettes generate emissions of polyaromatic hydrocarbons (PAHs) [6]. In this work, non-bituminous binders have been used in the briquettes to minimize the emissions of PAHs. These type of compounds are considered to be carcinogenic and therefore it is better to avoid them [6].

The coke performs three functions inside the blast furnace: acts as an iron ore reducing agent, provides heat and acts as a physical support. Coke is the most important raw material fed in the blast furnace, because it supports the burden as it descends down the furnace, enhance gas distribution and gas permeability in the shaft and facilitate the 
percolation of liquid iron and adsorption of dust. The use of a high quality coke in the blast furnace will result in higher productivity and lower hot metal costs. For these reasons, coke mechanical strength is one of the most important parameters for evaluating coke quality [7].

Coke strength is important throughout all phases of the steelmaking process. Before reaching the blast furnace, the coke undergoes physical deterioration during handling and transportation. In the blast furnace, the coke is subjected to slow abrasion as it travels down the furnace. Compression strength is also important because the coke forms a porous bed in the lower part of the blast furnace which needs to withstand the high loads without disintegrating. Low coke strength is one of the factors that can produce an inactive deadman that will deteriorate hot metal quality and eventually reduce campaign life [8].

Coke strength has been related to many different parameters. Mochizuki et al. found a positive correlation between the indirect tensile strength of coke prepared from pelletized samples and its maximum fluidity values [9]. In agreement with their observation, a recent study by Montiano et al. showed that the addition of increasing percentages of biomass to metallurgical coking blends reduces the maximum Gieseler fluidity in accordance with a logarithmic equation. These percentages of biomass addition also produce an impairment of coke strength as determined by means of the Japanese Industrial Standard JIS K2151(DI150/15 index: material remaining $+15 \mathrm{~mm}$ square hole after 150 revolutions) [2]. On the other hand, Ueki et al. attribute this impairment to the release of biomass volatile matter, arguing that connectivity between the coal particles during carbonization is inhibited by the release of the volatile matter from woody biomass [10]. Bulk density has also been proved to be an important parameter. Montiano et al. compared the strengths of cokes obtained by direct addition and partial briquetting, and concluded that the strength is greater when briquettes are used due to the increase in bulk density [11]. Qiu et al. found a linear relationship 
between MICUM cold mechanical strength indices $\left(M_{25}\right.$ i.e. percentage of coke with particle size $>25 \mathrm{~mm}$ after rotating $50 \mathrm{~kg}$ of coke 100 times, $M_{10}$ percentage of coke with particle size $>10 \mathrm{~mm}$ after rotating $50 \mathrm{~kg}$ of coke 100 times) and the relative content of macropores, indicating that this parameter has a large influence on coke mechanical strength [12]. Optical textural components, which represent the degree of structural order of coke pore walls, have also been related to coke quality [13]. With respect to the use of binders in briquettes, Sharma et al. have reported that a $\mathrm{C} / \mathrm{H}$ atomic ratio of the binders greater than 1 yields strong carbonized briquettes [14].

To the best of our knowledge, the present study is the first that aims at finding the best combination binder/biomass including four binders and four biomasses to produce high strength briquettes. Physical and chemical characterization is used to scientifically explain the mechanical strength of the bio-cokes. Finding a binder, less pollutant than bituminous binders, with good performance in relation with the strength of the briquettes is seen as an additional aim.

\section{Materials and methods}

Blends of biomass, coal and binder were briquetted in a hydraulic press in order to conform 15 briquettes of different composition. The briquettes contained 70 wt $\%$ of a bituminous coal, biomass (15 wt\%, except when molasses were employed as binder in which case 20 wt $\%$ was used) and binder (15 wt\%, except for molasses where $10 \mathrm{wt} \%$ was used). Four different biomasses were employed i.e. lignin (Lg), pine sawdust (SP), torrified pine sawdust (SPT) and a solid from the hydrothermal carbonization of lignocelulosic tree-pruning wastes $(\mathrm{BIOC})$. The binders included molasses (Mol), paraffin (Par), coal tar (T) and a 1:1 blend of tar and coal tar sludge (T/CTS). To acquire a deeper understanding of the effect of the binders, four briquettes were prepared with just the coal and binders. A more detailed description of the procedure applied to prepare the briquettes and of the materials used can be found elsewhere 
109 [15]. The nomenclature used for the briquettes is as follows i.e. Br (biomass-binder).

110 Therefore, $\operatorname{Br}(\mathrm{Lg}-\mathrm{T})$ is used for a briquette prepared from a ternary blend of coal, lignin

111 as biomass and tar as binder. Similarly, in the case of briquettes prepared from binary

112 blends i.e. coal and binder $\mathrm{Br}$ (binder) will be used. In this case $\mathrm{Br}(\mathrm{T})$ is used for a

113 briquette prepared from the blend coal and tar

Briquette density was calculated as the ratio between mass and volume.

Proximate analyses were performed following the ISO 562 and ISO 1171 standard procedures for volatile matter and ash content, respectively. The elemental analysis was determined with the aid of a LECO CHN-2000 for C, H and N (ASTM D-5773), a LECO S-144 DR for sulphur (ASTM D-5016) and a LECO VTF-900 for the direct determination of oxygen. The main characteristics of the raw materials are presented in

Table 1. The particle size of the biomasses used to prepare the briquettes is shown in

Table 2.

122

The thermoplastic properties were determined following the ASTM D2639-74 [15,16]

Table 1. Characteristics of the briquette components.

\begin{tabular}{lccccccccc}
\hline & Coal & SP & SPT & BIOC & Lg & Mol & Tar & CTS & Par \\
Ash $(w t \% d b)^{\mathrm{a}}$ & 7.3 & 0.2 & 0.4 & 6.1 & 2.5 & $2.8^{\mathrm{c}}$ & $0.4^{\mathrm{c}}$ & $1.7^{\mathrm{c}}$ & $0.1^{\mathrm{c}}$ \\
V.M. $(w t \% \mathrm{db})^{\mathrm{a}, \mathrm{b}}$ & 31.5 & 84.3 & 71.1 & 68.0 & 64.0 & $94.4^{\mathrm{c}}$ & $65.9^{\mathrm{c}}$ & $71.1^{\mathrm{c}}$ & $99.6^{\mathrm{c}}$ \\
$\mathrm{C}(\mathrm{wt} \% \mathrm{db})^{\mathrm{a}}$ & 81.2 & 50.9 & 59.8 & 59.8 & 64.7 & 26.5 & 90.3 & 84.2 & 85.1 \\
$\mathrm{H}(\mathrm{wt} \% \mathrm{db})^{\mathrm{a}}$ & 5.0 & 6.2 & 5.7 & 6.0 & 5.7 & 8.0 & 4.7 & 5.3 & 14.5 \\
$\mathrm{~N}(\mathrm{wt} \% \mathrm{db})^{\mathrm{a}}$ & 1.6 & 0.3 & 0.3 & 1.2 & 0.9 & 1.7 & 0.8 & 1.3 & 0.2 \\
$\mathrm{~S}(\mathrm{wt} \% \mathrm{db})^{\mathrm{a}}$ & 1.03 & $<0.05$ & $<0.05$ & 0.15 & 1.52 & 0.18 & 0.4 & 0.60 & $<0.05$ \\
$\mathrm{O}(\mathrm{wt} \% \mathrm{db})^{\mathrm{a}}$ & 4.8 & 44.7 & 35.5 & 25.5 & 26.3 & 55.9 & 3.0 & 8.2 & 0.3 \\
$\mathrm{C} / \mathrm{H}^{\mathrm{d}}$ & 1.35 & 0.68 & 0.87 & 0.83 & 0.95 & 0.28 & 1.60 & 1.32 & 0.49 \\
\hline
\end{tabular}


127 Table 2. Particle size distribution of the biomasses used in the preparation of the 128 briquettes expressed as wt\%.

\begin{tabular}{ccccccc}
\hline Sample & $>3 \mathrm{~mm}$ & $3-2 \mathrm{~mm}$ & $2-1 \mathrm{~mm}$ & $1-0.5$ & $0.5-0.2$ & $<0.212$ \\
\hline SP, SPT & 0.6 & 2.3 & 16.4 & 47.4 & 27.7 & 5.7 \\
BIOC & 21.2 & 16.9 & 24.1 & 15.3 & 11.4 & 11.3 \\
Lg & -- & -- & -- & -- & 2.6 & 97.5 \\
\hline
\end{tabular}

129

\subsection{Carbonization of the briquettes}

The briquettes were heated in a horizontal oven up to $1000^{\circ} \mathrm{C}$ at a rate of $3^{\circ} \mathrm{C} / \mathrm{min}$ under a $\mathrm{N}_{2}$ flow rate of $300 \mathrm{~mL} / \mathrm{min}$. A soaking time of $1 \mathrm{~h}$ was applied. The coke yield was calculated as the weight percentage of coke obtained from each briquette type.

\subsection{Mechanical strength tests}

The micro-strength of the cokes was determined by the method used by Ragan and Marsh [17]. Two charges of the same coke $(2 \mathrm{~g}, 0.6-1.18 \mathrm{~mm})$ were placed in two cylinders with 12 steel ball-bearings. The samples were subjected to 800 rotations at a speed of $25 \mathrm{rpm}$. Three indices were derived after sieving: $R_{1}(w t \%>600 \mu \mathrm{m})$, $R_{2}(w t \% 600-212 \mu m)$ and $R_{3}(w t \%<212 \mu m)$. The higher the $R_{3}$ index, the lower the mechanical strength of the cokes. The results have a \pm 0.5 margin of error [18].

Cokes from briquettes prepared with lignin were selected to undergo the compression test. 16 coke cores were obtained from the 4 carbonized briquettes ( 4 for each one). The samples were cubic in shape with a base of approximately $10 \times 10 \mathrm{~mm}$. The ends were polished using sandpaper. The compression tests were carried out using an Instron Materials tester. Compression was applied to the samples at a displacement rate of $0.3 \mathrm{~mm} / \mathrm{min}$ until failure occurred [19]. The initial failure stress was measured as the stress at which the first failure occurred. Stiffness was calculated as the slope of the initial linear elastic region and specimen deformation was measured as the strain at the initial failure stress [19]. 
151 The true density $\left(\rho_{\mathrm{He}}\right)$ of the samples was measured by means of helium 152 picnometry on a Micromeritics Accupyc 1330 Pycnometer. Their apparent density $\left(\rho_{\mathrm{Hg}}\right)$ 153 was determined using mercury at $0.1 \mathrm{MPa}$ on a Micromeritics autopore IV 9500 154 mercury porosimeter. From the true and apparent densities, the open porosity $(\varepsilon)$, corresponding to pore sizes of less than $12 \mu \mathrm{m}$, was calculated by means of the following equation:

$$
\varepsilon(\%)=\left(1-\frac{\rho_{\mathrm{Hg}}\left(\mathrm{g} / \mathrm{cm}^{\mathrm{a}}\right)}{\rho_{\mathrm{He}}\left(\mathrm{g} / \mathrm{cm}^{\mathrm{s}}\right)}\right) \times 100
$$

The total pore volume $\left(\mathrm{V}_{\mathrm{T}}\right)$ was obtained from the equation:

$$
\mathrm{V}_{\mathrm{T}}\left(\mathrm{cm}^{3} / \mathrm{g}\right)=\left(\frac{1}{\rho_{\mathrm{Hg}}\left(\mathrm{g} / \mathrm{cm}^{3}\right)}-\frac{1}{\rho_{\mathrm{He}}\left(\mathrm{g} / \mathrm{cm}^{3}\right)}\right)
$$

The pore size distribution was calculated by applying increasing pressure to the sample from 0.1 up to $227 \mathrm{MPa}$. This resulted in pore sizes in a range of $12 \mu \mathrm{m}$ $5.5 \mathrm{~nm}$ according to the Washburn equation. The biomasses used for the textural characterization were analyzed as received. The cokes were first ground to a particle size of $0.6-1.18 \mathrm{~mm}$. The pore sizes were classified into two categories: macropores $(12 \mu \mathrm{m}>\mathrm{dp}>50 \mathrm{~nm})$ and mesopores $(50 \mathrm{~nm}>\mathrm{dp}>5.5 \mathrm{~nm})$.

\subsection{Polarized light microscopy (PLM)}

The samples with a particle size of $0.6-1.18 \mathrm{~mm}$ were mounted in resin for examination by optical microscopy. They were then smoothed using silicon-carbide papers before being polished with fine alumina. To assess the textural composition of the coke, the polished surfaces were examined using a polarized light microscope fitted with crossed polars and a full-wave retarder plate. The optical appearance at 250 
172 points of the polished surface of the cokes was evaluated using the classification

173 developed by Patrick [20].

1743 Results and Discussion

\subsection{Strength of biocokes}

The micro-strengths of the cokes from the briquettes with and without biomass are

177 shown in Table 3 and Figure 1. The cokes present differences depending on the type

178 of biomass used. The results of this study, in the case of ternary blends, show that the

179 lowest $R_{3}$ indices correspond to the briquettes prepared with lignin and T/CTS as

180 binder $\left(\mathrm{R}_{3}=54 \mathrm{wt} \%\right)$. On the other hand, the worst strength corresponds to the

181 briquettes containing pine sawdust with molasses and paraffin as binders.

182 Table 3. Gieseler fluidity and coke yield of the blends that made up the briquettes and 183 micro-strength indices of the cokes.

\begin{tabular}{|c|c|c|c|c|c|}
\hline Sample & MF $\left(d d p m^{a}\right)^{b}$ & CY (\%) & $\mathrm{R}_{1}$ & $\mathrm{R}_{2}$ & $\mathrm{R}_{3}$ \\
\hline $\operatorname{Br}(\mathrm{T})$ & $29360^{c}$ & 70.7 & 1.6 & 45 & 53 \\
\hline $\mathrm{Br}(\mathrm{T} / \mathrm{CTS})$ & $29406^{c}$ & 69.7 & 2.2 & 49 & 49 \\
\hline $\mathrm{Br}(\mathrm{Mol})$ & 867 & 68.0 & 2.9 & 40 & 57 \\
\hline $\mathrm{Br}(\mathrm{Par})$ & 27364 & 66.3 & 2.2 & 42 & 55 \\
\hline $\mathrm{Br}(\mathrm{BIOC}-\mathrm{T})$ & 2268 & 66.8 & 1.4 & 39 & 60 \\
\hline $\mathrm{Br}(\mathrm{BIOC}-\mathrm{T} / \mathrm{CTS})$ & 2125 & 65.7 & 2.0 & 40 & 58 \\
\hline $\mathrm{Br}(\mathrm{BIOC}-\mathrm{Mol})$ & 69 & 59.9 & 1.3 & 32 & 67 \\
\hline $\mathrm{Br}(\mathrm{BIOC}-\mathrm{Par})$ & 395 & 57.8 & 1.2 & 31 & 68 \\
\hline $\operatorname{Br}(\mathrm{Lg}-\mathrm{T})$ & 389 & 65.8 & 1.9 & 42 & 56 \\
\hline Br(Lg-T/CTS) & 340 & 65.7 & 2.2 & 44 & 54 \\
\hline $\operatorname{Br}(\mathrm{Lg}-\mathrm{Mol})$ & 0 & 63.2 & 2.2 & 39 & 59 \\
\hline $\mathrm{Br}(\mathrm{Lg}-\mathrm{Par})$ & 284 & 59.8 & 1.4 & 34 & 65 \\
\hline Br(SP-T/CTS) & 2046 & 61.9 & 1.1 & 35 & 64 \\
\hline $\mathrm{Br}(\mathrm{SP}-\mathrm{Mol})$ & 242 & 57.4 & 1.3 & 26 & 73 \\
\hline $\mathrm{Br}$ (SP-Par) & 922 & 55.2 & 1.1 & 28 & 70 \\
\hline Br(SPT-T) & 962 & 63.4 & 1.0 & 27 & 72 \\
\hline Br(SPT-T/CTS) & 999 & 63.8 & 1.3 & 31 & 67 \\
\hline Br(SPT-Mol) & 11 & 61.0 & 2.1 & 31 & 67 \\
\hline Br(SPT-Par) & 526 & 57.1 & 0.8 & 26 & 73 \\
\hline
\end{tabular}

184 a: dial divisions per minute; b: data from [15]; c: Maximum value that can registered by 185 the equipment. 


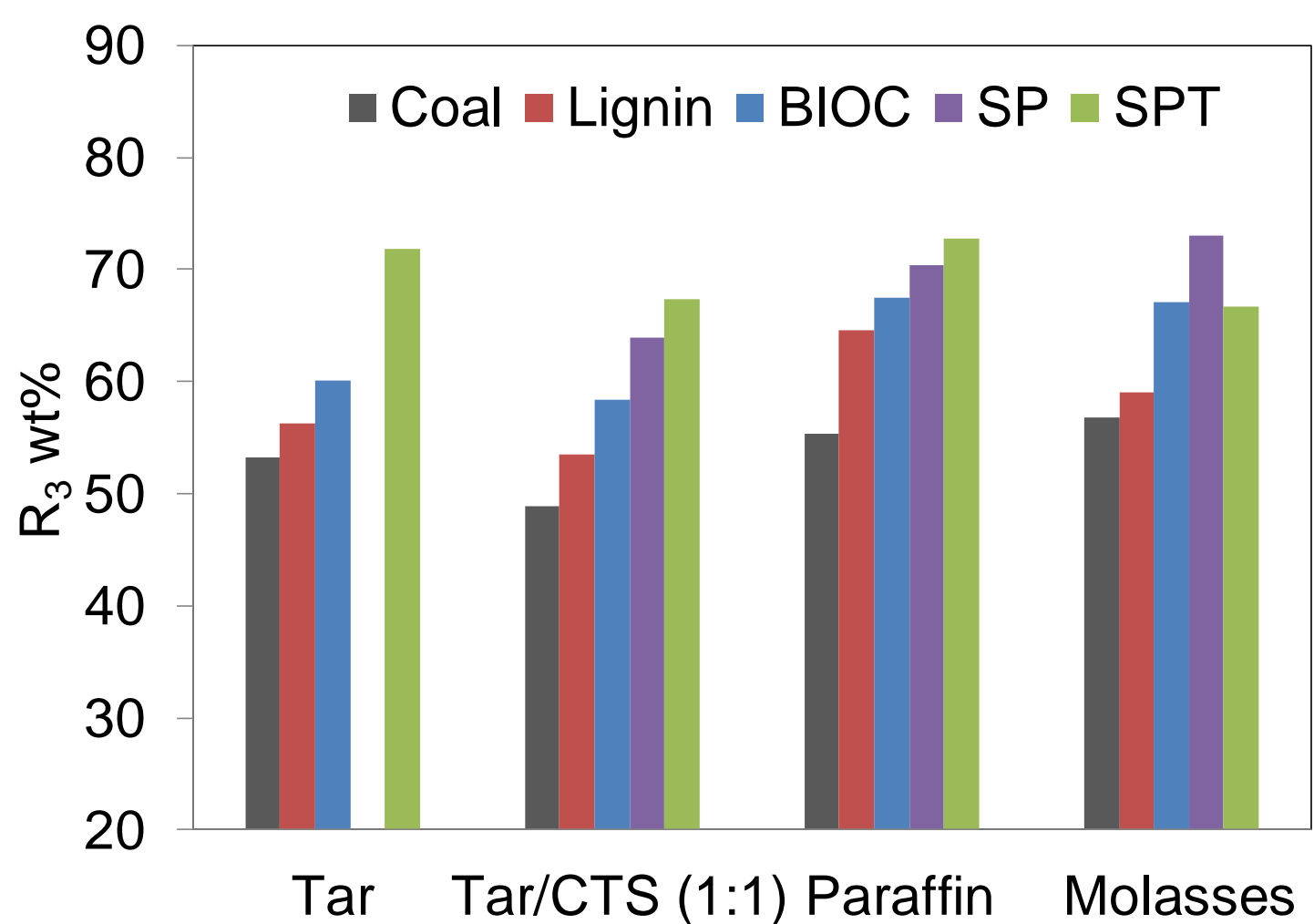

Figure 1. Variation of the $R_{3}$ index as a function of the binder used in the briquettes. "Coal" corresponds to briquettes from binary blends. strength:

The following order was established proceeding from the highest to the lowest
Biomasses: lignin > BIOC > SP > SPT.
Binders: T/CTS > T > Molasses $>$ Paraffin

Previous studies have shown that lignin produces a strong char. Lignin has been used in combination with anthracite fines to produce foundry coke briquettes and it has been observed that the strength of the briquettes increases with an increase in hardwood lignin concentration of around 6 wt.\% [21,22]. Another research work on the strength of a lignin hydrochar reported $a \mathrm{R}_{3}$ index of $69 \%$ [23].

As for the binders, the best strength was obtained with briquettes prepared with $T$ and the blend T/CTS, whereas, the worst was obtained with briquettes made using paraffin. In this work, for comparison purposes a series of briquettes made only with 
202

203

204

205

206

207

208

209

210

211

212

213

214

215

216

217

218

219

220

221

222

223

coal and the four binders was prepared. The strength of these briquettes proved to be greater than that of equivalent briquettes prepared with biomass (Figure 1, grey bars). As in the case of the biomass briquettes the best binder was the $1: 1$ blend of tar with coal tar sludge. This is because CTS is composed of a soluble fraction which can be expected to have a binding effect similar to that of coal-tar but also an insoluble fraction that acts as filler, thereby contributing to an increase in strength [24]. The combination lignin and molasses produces a coke with a mechanical strength similar to that of the coke without lignin. This combination has the advantage of the higher percentage of biomass in the briquette and the lack of bituminous binder.

Since lignin is the biomass that produces the best microstrength results, the four cokes from briquettes prepared with lignin were selected to undergo compression tests. Table 4 shows the mean value of the initial failure strength for each coke together with the standard deviation and the stiffness and strain at initial failure. An example of the curves obtained for each coke is presented in Figure 2. The highest compression strength value corresponds to the coke with T/CTS as binder which agrees with the results of the microstrength test. The compression strength of the cokes presented in this research work is similar to that of the bio-cokes produced with the addition of lignin to a coking coal [25]. The shapes of the stress-strain curves corresponding to the four briquettes are similar. Initially they all display a linear region corresponding to the linear elasticity zone which is followed by the collapse of the sample.

Table 4. Results of the compression tests.

\begin{tabular}{lcccc}
\hline & $\begin{array}{c}\text { Initial Faliure } \\
\text { Strength } \\
(\mathrm{MPa})\end{array}$ & $\begin{array}{c}\text { St. Dev Initial } \\
\text { Faliure Strength } \\
(\mathrm{MPa})\end{array}$ & $\begin{array}{c}\text { Stiffness } \\
(\mathrm{MPa})\end{array}$ & $\begin{array}{c}\text { Strain at initial } \\
\text { failure }\end{array}$ \\
\hline $\mathrm{Briquette}$ & 4.24 & 2.8 & 144.71 & 0.018 \\
$\mathrm{Br}(\mathrm{Lg}-\mathrm{Mol})$ & 13.38 & 1.1 & 490.15 & 0.018 \\
$\mathrm{Br}(\mathrm{Lg}-\mathrm{Par})$ & 15.41 & 1.4 & 529.81 & 0.022 \\
$\mathrm{Br}(\mathrm{Lg}-\mathrm{T} / \mathrm{CTS})$ & 24.25 & 1.8 & 756.72 & 0.022 \\
\hline
\end{tabular}




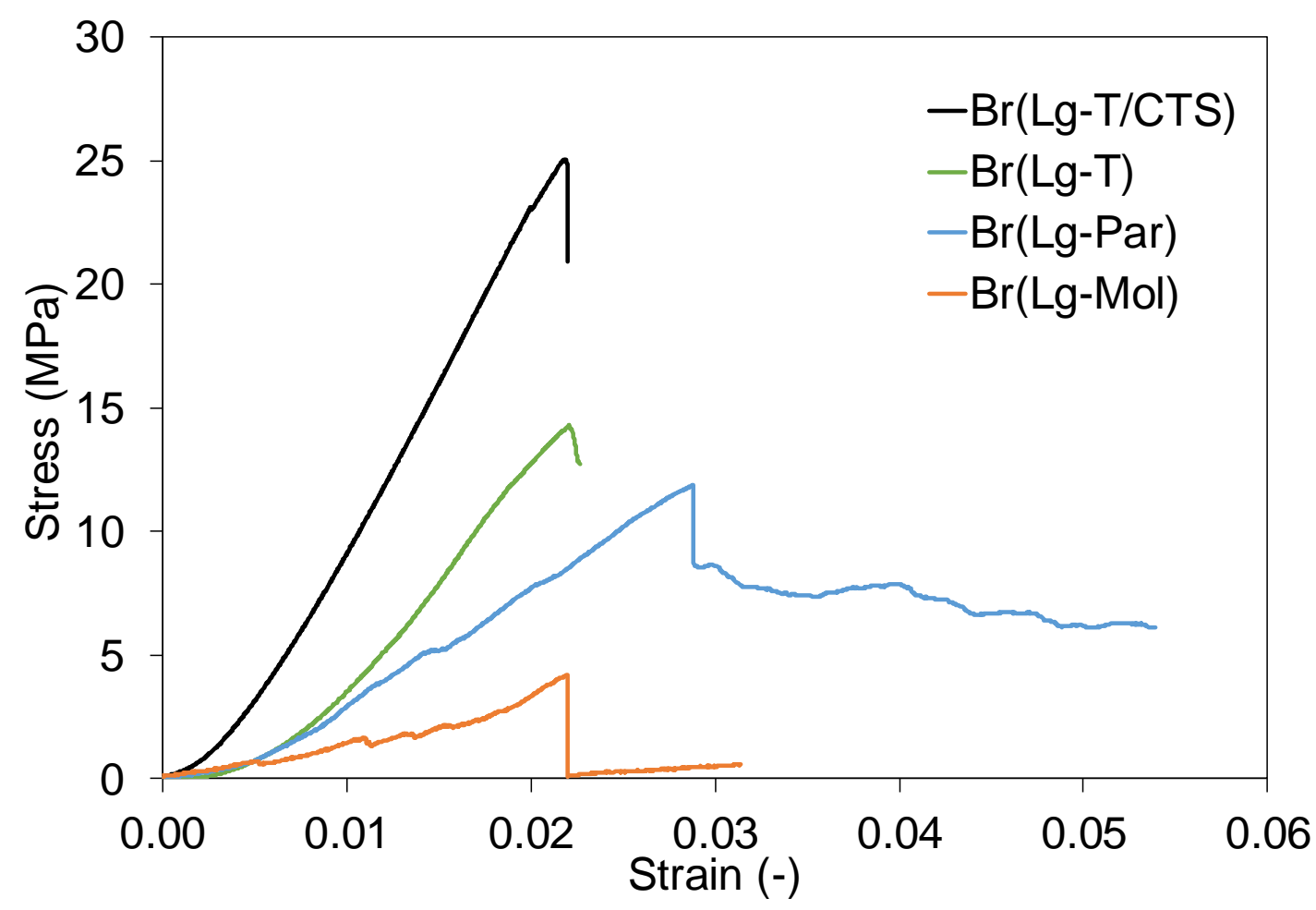

224

Figure 2. Compression tests of the cokes from briquettes prepared with lignin at a head displacement rate of $0.3 \mathrm{~mm} / \mathrm{min}$.

3.2 Relationship of bio-coke strength with the main characteristics of the raw materials. that determines the coke strength $[9,26]$, although the relationship between these two parameters is not clear-cut, i.e. no linear relationship between the maximum Gieseler fluidity (MF) of the briquettes and the strength of cokes was observed $\left(r^{2}=0.38\right)$. Nevertheless, modification of the thermoplastic properties of a coal is bound to have an effect on the structure of the resulting cokes, and consequently on their strength. The observed order for the positive effect of the binders on the fluidity of the blends was: T>T/CTS > paraffin>molasses (Table 3).

In the case of binary blends (i.e. briquettes prepared only with coal and binder), the lowest strengths (i.e. highest $R_{3}$ values) corresponded to the lowest fluidity values i.e. 
$241 \mathrm{Br}(\mathrm{Mol})$. Nevertheless, it should be taken into account that the difference in strength

242 between the cokes of $\mathrm{Br}(\mathrm{Mol})$ and $\mathrm{Br}(\mathrm{Par})$ is low (two points difference in $\mathrm{R}_{3}$ ) compared

243 to the difference in fluidity (MF of $\operatorname{Br}(\mathrm{Mol})=867$ ddpm and $\mathrm{MF}$ of $\operatorname{Br}(\mathrm{Par})=27364$

$244 \mathrm{ddpm}$ ). In the case of the ternary blends (i.e. briquettes prepared with coal, biomass

245 and binder) the results of micro-strength and compression strength are slightly

246 different. Whereas paraffin produced the worst micro-strengths in most cases (Table

247 3), the compression strength of those bio-cokes is superior to those prepared with

248 molasses (Table 4). Consequently the fact that it does not decrease coal fluidity

249 (MF Coal $=27915 \mathrm{ddpm}$ ) due to its limited participation in H-transfer reactions [27],

250 bears no relation to its effect on the coke strength of the briquettes. Both bituminous

251 binders produce the greatest micro- and compression strengths.

252

253

254

255

256

257

258

259

260

261

262

263

264

265

266

267

On the other hand, it has been shown that biomass fluidity as determined by hightemperature rheometry does not affect blend fluidity since at the temperatures of coal plastic stage, biomass is already present as a char [15]. The influence of biomass on fluidity is related to the porosity and yield of the char from the biomass $[15,28]$. Pine sawdust is the biomass which causes the least impairment of coal fluidity, whereas lignin produces a drastic reduction in fluidity but also coke with the highest strength (Table 3).

Sulphur content is a parameter of great importance for metallurgical cokes since its content influences pig iron quality and needs to be lower than $1 \mathrm{wt} \%$, although sometimes cokes with a sulphur content of $1.5 \mathrm{wt} \%$ can be used [7]. The sulphur content of the lignin in this study is relatively high (1.52 wt\% Table 1) compared with the other biomasses and binders that have S contents in the 0.54 and $0.02 \mathrm{wt} \%$ range (Table 1). Biomass can be used to lower the total $S$ content of a coking blend. The sulphur content of coal has been related to coal strength, but the results are somewhat contradictory. North reported a positive relationship between sulphur and the MICUM cold mechanical strength index M-40 [29], whereas, Wei et al. saw a positive 
relationship with the abrasivity MICUM index i.e. M-10 [30]. Our results show that sulphur content and the micro-strength index $R_{3}(<212 \mu \mathrm{m})$ are negatively related $\left(r^{2}=0.77\right)$, which suggests that sulphur content has a positive effect on strength.

Sharma et al. observed a positive relationship between the $\mathrm{C} / \mathrm{H}$ ratio of the binder and coke strength and found that a minimum value of 1 was necessary to obtain strong carbonized briquettes [14]. In our case, the only binders that have a $\mathrm{C} / \mathrm{H}$ ratio greater than 1 are tar and CTS, with values of 1.60 and 1.32, respectively (Table 1). In general, the cokes with the greatest strength (lowest $R_{3}$ and highest initial failure stress) were prepared with these binders (Figures 1 and 2, Tables 3 and 4). However, the correlation coefficient corresponding to the relationship between the $R_{3}$ index and the $\mathrm{C} / \mathrm{H}$ ratio of the binder is very low $\left(\mathrm{r}^{2}=0.16\right)$. This may be due to the fact that the binders used have completely different origins and characteristics. The $\mathrm{C} / \mathrm{H}$ ratio is normally used to indicate the degree of aromaticity, but in the present case paraffin has a higher value than the molasses of this ratio, although it is less aromatic. Paraffin does not have any aromatic structures whereas molasses has some aromatic structures that are typical of lignocellulosic biomass [15].

The $\mathrm{C} / \mathrm{H}$ ratios of the biomasses studied in this work are: lignin $(0.95)>$ $\operatorname{SPT}(0.87)>\operatorname{BIOC}(0.83)>\mathrm{SP}(0.68)$ which gives an indication of their aromaticity. The lignin biomass component which has the most aromatic structure and the heattreated biomass are generally considered to be more aromatic than pristine biomasses [31]. Our results show that the $\mathrm{C} / \mathrm{H}$ ratio of the biomass does not have a great influence on the strength of briquette coke.

The effect of "inert" additives such as petroleum cokes and coke breeze on the strength of cokes depends on their volatile matter content which is seen as an indication of the potential of the additive to form a good bond with the coke matrix [26]. In the present case, an increase in the volatile matter content of the blend used to prepare the briquettes is directly related to higher $R_{3}$ values, as shown in Figure $3\left(r^{2}=0.74\right)$. 
295 Given that the coke yield obtained from carbonization of the briquettes is inversely related to its VM content $\left(r^{2}=0.93\right)$, the CY must also be related to $R_{3}\left(r^{2}=0.76\right)$. In agreement with the characteristics of the blend components (Table 1), the highest coke yield corresponds to the briquettes prepared with lignin and BIOC as biomasses and coal tar and coal tar sludge (CTS) as binders, i.e. those that show the greatest strength. with lignin and the two bituminous binders which are the ones that have the lowest volatile matter content (i.e. around $42 \mathrm{wt} \%$ ). Bituminous binders due to their higher coke yield contribute to the formation of a stronger coke matrix between the char from the biomass and the coke from the coal.

The particle size of the additives is also seen as an important parameter that influences mechanical strength. It is generally considered that small particle sizes in petroleum coke or coke breeze produce less microcracks at the interface between the additive and the coke from the coal resulting in greater mechanical strength [32]. In the case of biomass, additions of $1 \mathrm{wt} \%$ with particle size between 0.4 and $0.8 \mathrm{~mm}$ had a deleterious effect on coke strength, whereas when biomass with a particle size of $2 \mathrm{~mm}$ was used, the strength of the coke was similar to that of the coke undergoing no addition [33]. Our results also indicate that the coke from briquettes containing BIOC has greater strength than those with SP and SPT which have smaller particle sizes (Table 2). A larger particle size is associated with a smaller contact area between the biomass particle and the coke but biomass density also affects this relationship [33]. More detailed studies are necessary to evaluate the effect of the particle size of the biomass used in the preparation of the briquettes on the strength of the coke. 


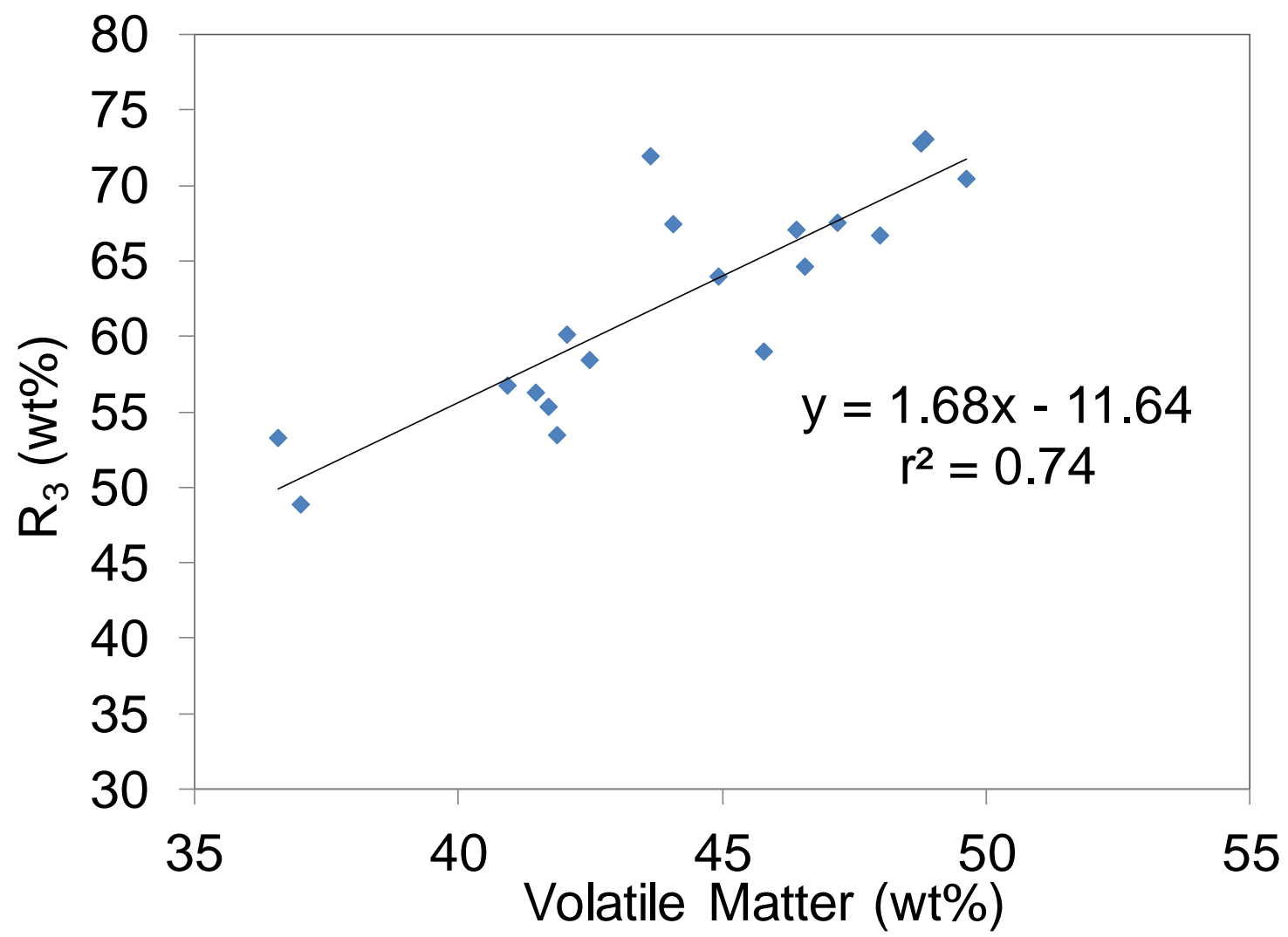

319 Figure 3. Relationship between the volatile matter content of the briquettes and the $\mathrm{R}_{3}$ index.

Various methods can be applied to increase the bulk density of the biomass in order to improve the strength of the resulting cokes, such as torrefaction [10] and briquetting [11]. In the present research work both methods were used.

Figure 4 shows the variation of briquette density as a function of its composition. The gray bars represent the values of the briquettes prepared without biomass. The average density of these briquettes is $1.09 \pm 0.02 \mathrm{~g} / \mathrm{cm}^{3}$, which is similar to the values obtained for the ternary blends containing $\mathrm{BIOC}$ and lignin $\left(1.04-1.17 \mathrm{~g} / \mathrm{cm}^{3}\right)$. Pine sawdust and torrified pine sawdust produced the lowest densities when blended with coal tar, tar/CTS and molasses $\left(0.75-0.92 \mathrm{~g} / \mathrm{cm}^{3}\right)$, whereas the densities of the briquettes prepared by blending SP and SPT with paraffin were higher (1.00-1.07 $\left.\mathrm{g} / \mathrm{cm}^{3}\right)$ and therefore similar to 
332 the rest of the briquettes. Paraffin, when slightly heated to $55^{\circ} \mathrm{C}$, was transformed into a

333 non-viscous liquid that readily filled the porous structure of all the biomasses. As a result, 334 there are no differences regardless of the biomass used and the density values 335 corresponding to the briquettes prepared with paraffin as binder are very similar.

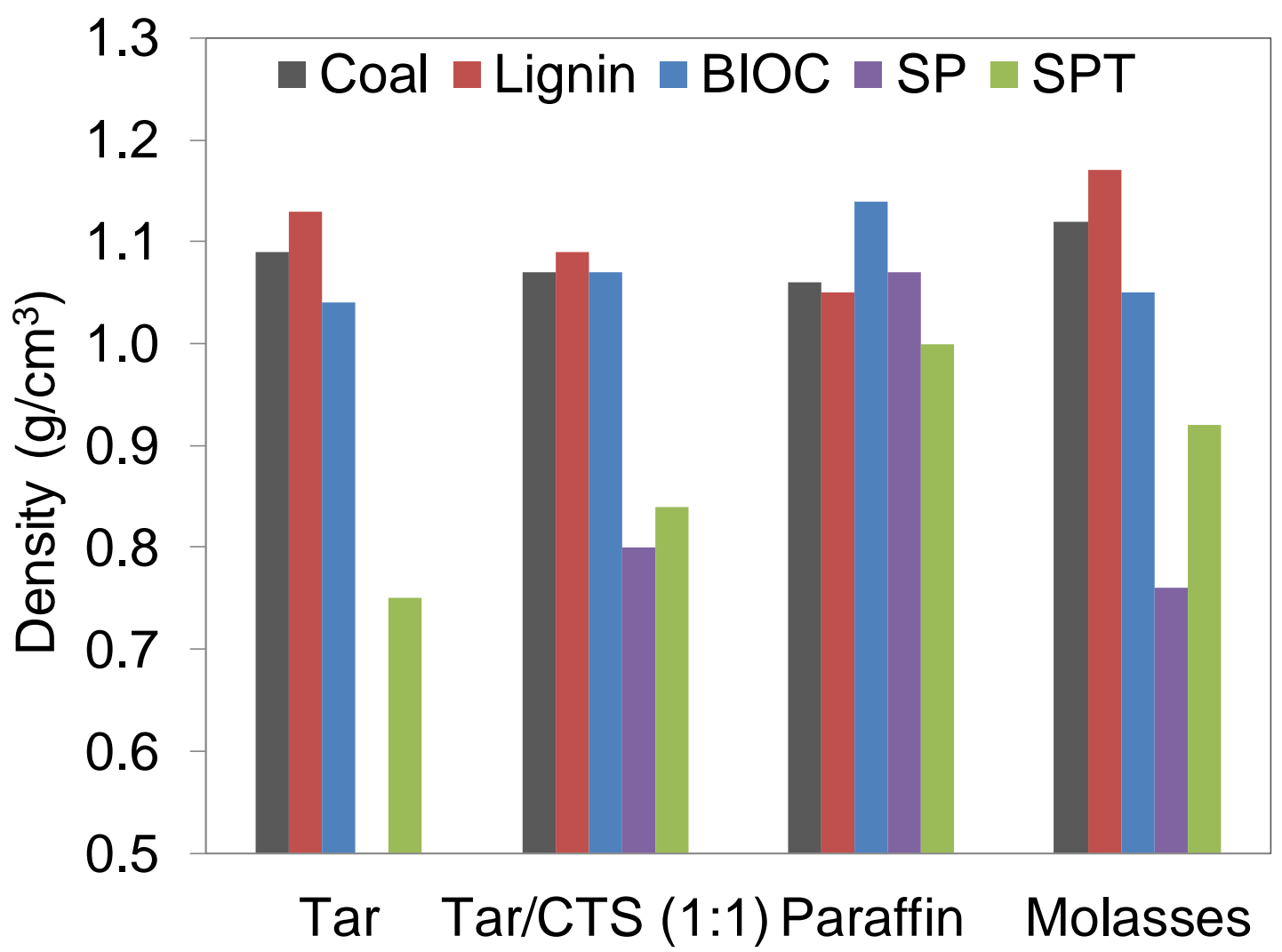

Figure 4. Density of the briquettes as a function of the biomass and binder. "Coal" corresponds to briquettes from binary blends.

Figure 5 shows the relationship between the $R_{3}$ index and briquette density. Each line corresponds to the values obtained for briquettes prepared with one binder and the four biomasses. The paraffin was not taken into consideration because no variation was observed in the density values. The correlation coefficients $\left(r^{2}\right)$ observed were higher than 0.8. The briquettes prepared with lignin and BIOC showed the highest densities and accordingly the resulting cokes were stronger. To evaluate the effect of 
the binder, the density and strength of the briquettes prepared without biomass were compared, but the density values for these briquettes were too similar to allow any clear conclusion apart from the fact that biomass is the main factor influencing briquette density.

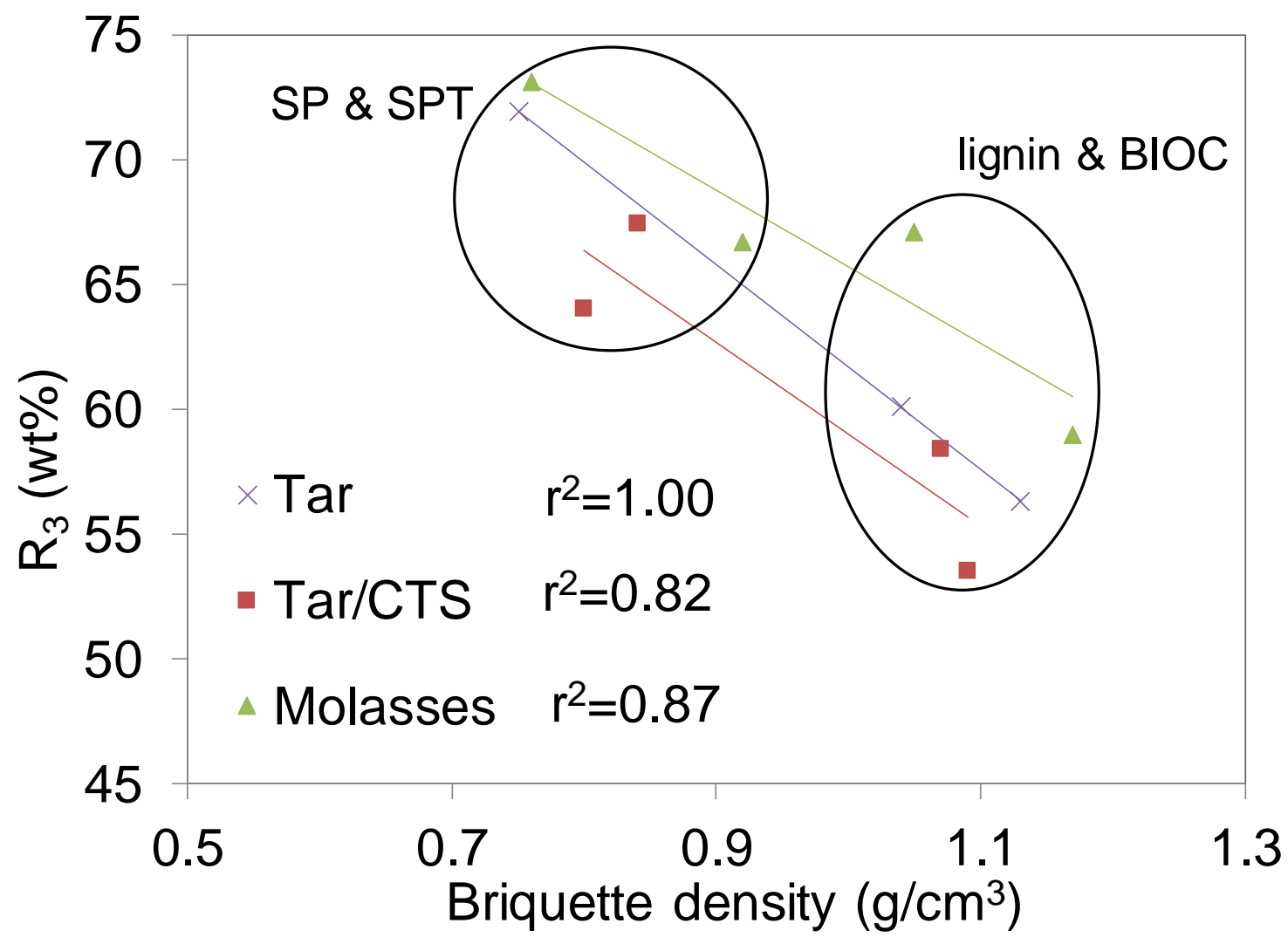

Figure 5 . Variation of the $R_{3}$ index as a function of the briquette density.

The porous structure of the biomasses was studied to establish whether the differences in density of the briquettes were related to the porous texture of the biomasses. Table 5 shows their true and apparent densities, as determined by $\mathrm{He}$ and $\mathrm{Hg}$ picnometry, respectively, together with their open porosity and macro-, meso- and total pore volumes. It can be seen that the largest macropore percentage corresponds to BIOC (81.5\%), followed by lignin $(67.7 \%)$, while both sawdusts have lower percentages of macropore, around $37 \%$. Our results indicate that the biomasses that are present in 
briquettes with the highest densities and greatest strengths have the highest pore volume and highest percentage of macropores. This is because it is easier for the binder to penetrate the structure of the biomass and produce briquettes with a greater density.

Table 5. Textural characteristics of the biomasses used.

\begin{tabular}{lcccccc}
\hline Sample & $\begin{array}{c}\rho_{\mathrm{Hg}} \\
\left(\mathrm{g} / \mathrm{cm}^{3}\right)\end{array}$ & $\begin{array}{c}\rho_{\mathrm{He}} \\
\left(\mathrm{g} / \mathrm{cm}^{3}\right)\end{array}$ & $\begin{array}{c}\mathrm{V}_{\text {total }} \\
\left(\mathrm{cm}^{3} / \mathrm{g}\right)\end{array}$ & $\begin{array}{c}\varepsilon \\
(\%)\end{array}$ & $\begin{array}{c}\mathrm{V}_{\text {macro }} \\
(\%)\end{array}$ & $\begin{array}{c}\mathrm{V}_{\text {meso }} \\
(\%)\end{array}$ \\
\hline BIOC & 0.605 & 1.357 & 0.916 & 55.4 & 81.5 & 3.9 \\
$\mathrm{SP}^{*}$ & 0.688 & 1.407 & 0.742 & 51.1 & 36.6 & 1.3 \\
$\mathrm{SPT}$ & 0.735 & 1.399 & 0.645 & 47.5 & 37.0 & 2.0 \\
Lg & 0.650 & 1.319 & 0.780 & 50.7 & 67.7 & 4.0 \\
\hline
\end{tabular}
$\rho_{\mathrm{Hg}}$ : Apparent density. $\rho_{\mathrm{He}}:$ True density. $\mathrm{V}_{\text {total }}$ : Total pore volume. $\mathrm{V}_{\text {macro }}$ : Macropore volume. $V_{\text {meso }}$ : Mesopore volume. ${ }^{*}$ data from reference [34].

3.4 Porous structure of briquette cokes

The porous structure of cokes is known to influence their mechanical strength. Indeed, a relationship has been claimed to exist between the tensile strength of metallurgical cokes and pore structural parameters [35].

In a previous study by Montiano et al. it was reported that the addition of sawdust produces an increase in total porosity mainly due to the decrease in the apparent density of the material. However, no relationship was established between the mechanical strength results and their porosity determinations [2]. It has also been reported that, in general, for the same level of addition, partial briquetting produces cokes with a lower total porosity than the direct addition of the briquette components, as a consequence of their higher bulk density [11]. The porous texture of the cokes prepared from the briquettes prepared with T/CTS as binder and the four biomasses is presented in Table 6 . This binder was selected because it is very effective in increasing 
381

mechanical strength. The biomass that produced cokes with the greatest proportion of macropores was SPT whereas Lg produced the lowest. The trend observed clearly indicates there is a relationship between high percentages of macropores and cokes of lower strength.

Table 6. Porous characteristics of cokes from briquettes prepared with T/CTS as binder.

\begin{tabular}{lcccccc}
\hline Sample & $\begin{array}{c}\rho_{\mathrm{Hg}} \\
\left(\mathrm{g} / \mathrm{cm}^{3}\right)\end{array}$ & $\begin{array}{c}\rho_{\mathrm{He}} \\
\left(\mathrm{g} / \mathrm{cm}^{3}\right)\end{array}$ & $\begin{array}{c}\mathrm{V}_{\text {total }} \\
\left(\mathrm{cm}^{3} / \mathrm{g}\right)\end{array}$ & $\begin{array}{c}€ \\
(\%)\end{array}$ & $\begin{array}{c}\mathrm{V}_{\text {macro }} \\
(\%)\end{array}$ & $\begin{array}{c}\mathrm{V}_{\text {meso }} \\
(\%)\end{array}$ \\
\hline $\operatorname{Br}(\mathrm{BIOC-T/CTS})$ & 1.374 & 1.793 & 0.170 & 23.4 & 59.4 & 4.0 \\
$\operatorname{Br}(\mathrm{Lg}-\mathrm{T} / \mathrm{CTS})$ & 1.551 & 1.804 & 0.091 & 14.0 & 40.4 & 5.3 \\
$\operatorname{Br}(\mathrm{SP}-\mathrm{T} / \mathrm{CTS})$ & 1.489 & 1.945 & 0.158 & 24.4 & 45.3 & 3.7 \\
$\mathrm{Br}(\mathrm{SPT}-\mathrm{T} / \mathrm{CTS})$ & 1.357 & 1.768 & 0.171 & 23.3 & 61.5 & 4.0 \\
\hline
\end{tabular}

$\rho_{\mathrm{Hg}}$ : Apparent density. $\rho_{\mathrm{He}}$ : True density. $\mathrm{V}_{\text {total }}$ : Total pore volume. $\mathrm{V}_{\text {macro }}$ : Macropore volume. $V_{\text {meso: }}$ : Mesopore volume.

\subsection{Polarized light microscopy (PLM)}

Metallurgical coke is a composite material whose strength and reactivity depend on its content in isotropic carbon and inerts, the size and shape of the anisotropic carbon units, and the nature of the interfaces between the textural components $[13,36,37]$. In this study the components present in the cokes were divided into two types of anisotropic components (i.e. flow and mosaic), an isotropic component and two sizes of inerts (Table 7). Three series of cokes were analysed: 1. briquettes without any biomass, 2. briquettes prepared with $\mathrm{BIOC}$ and all four binders and 3 . briquettes prepared with one binder (i.e. T/CTS) and four biomasses. Figure 6 contains six micrographs. The top three show the appearances of chars from biomasses BIOC (a), $\mathrm{SP}(\mathrm{b})$, and $\mathrm{Lg}(\mathrm{c})$ and the bottom three images of the briquettes $\mathrm{Br}(\mathrm{BIOC}-\mathrm{Mol}), \mathrm{Br}(\mathrm{SP}$ $\mathrm{T} / \mathrm{CTS})$ and $\mathrm{Br}(\mathrm{Lg}-\mathrm{T} / \mathrm{CTS})$. Figure 7 contains photomicrographs of the cokes from 
404 briquettes prepared without any biomass. The appearance of BIOC and SP (Figure 6a 405 and $6 \mathrm{~b}$ ) is similar to that of inerts inherent in coke from coal, whereas, lignin is 406 completely different because it agglomerates and forms an isotropic type component 407 (Figure $6 c$ ). Positions $1 d, 2 d$ and $3 d$ in Figure $6 d$ correspond to a large inert 408 component, a mosaic type component and a small inert well integrated within the coke 409 matrix, respectively. It is not possible to determine whether the large inert comes from 410 the BIOC present in the briquette or whether it is inherent in the coal. The appearance 411 of the textural component on the right hand side of Figure $6 e$ of the briquette $\mathrm{Br}(\mathrm{SP}$ $412 \mathrm{~T} / \mathrm{CTS}$ ) is similar to that of Figure $6 \mathrm{~b}$ corresponding to SP. Similarly, position $1 \mathrm{f}$ in 413 Figure $6 f$ appears to represent lignin (Figure 6c), whereas in position $2 f$ of Figure 6 an 414 area of mosaics is apparent.

415

416 Table 7. Textural composition (vol.\%) of cokes as determined by PLM.

\begin{tabular}{lccccc}
\hline Sample & Flow & Mosaic $^{\text {a }}$ & Isotropic & $\begin{array}{c}\text { Inert } \\
\text { small }\end{array}$ & $\begin{array}{c}\text { Inert } \\
\text { large }\end{array}$ \\
\hline $\mathrm{Br}(\mathrm{T})$ & 15 & 65 & 3 & 8 & 9 \\
$\mathrm{Br}(\mathrm{T} / \mathrm{CTS})$ & 17 & 66 & 2 & 5 & 10 \\
$\mathrm{Br}(\mathrm{Mol})$ & 8 & 51 & 21 & 6 & 13 \\
$\mathrm{Br}(\mathrm{Par})$ & 19 & 61 & 6 & 6 & 9 \\
$\mathrm{Br}(\mathrm{BIOC}-\mathrm{T})$ & 6 & 49 & 10 & 11 & 24 \\
$\mathrm{Br}(\mathrm{BIOC}-\mathrm{T} / \mathrm{CTS})$ & 8 & 46 & 13 & 10 & 24 \\
$\mathrm{Br}(\mathrm{BIOC}-\mathrm{Mol})$ & 2 & 39 & 18 & 10 & 31 \\
$\mathrm{Br}(\mathrm{BIOC}-\mathrm{Par})$ & 6 & 45 & 15 & 7 & 27 \\
$\mathrm{Br}(\mathrm{Lg}-\mathrm{T} / \mathrm{CTS})$ & 11 & 49 & 21 & 6 & 13 \\
$\mathrm{Br}(\mathrm{SPT} / \mathrm{CTS})$ & 7 & 52 & 13 & 7 & 21 \\
$\mathrm{Br}$ (SPT-T/CTS $)$ & 10 & 44 & 15 & 5 & 26 \\
\hline
\end{tabular}


419 coal and molasses, with position 1a indicating an area of transition between isotropic 420 material and fine grained mosaics and position 2a representing coarse mosaics. It can 421 be seen that there is a sharp interface between the two. Position $1 \mathrm{~b}$ of Figure $7 \mathrm{~b}$ shows 422 inherent inerts fully integrated within the coke matrix. Figure $7 c$ shows a mosaic and a 423 large inert at positions $1 \mathrm{c}$ and $2 \mathrm{c}$ respectively, whereas position $3 \mathrm{c}$ in Figure 7 shows a 424 flow type component.

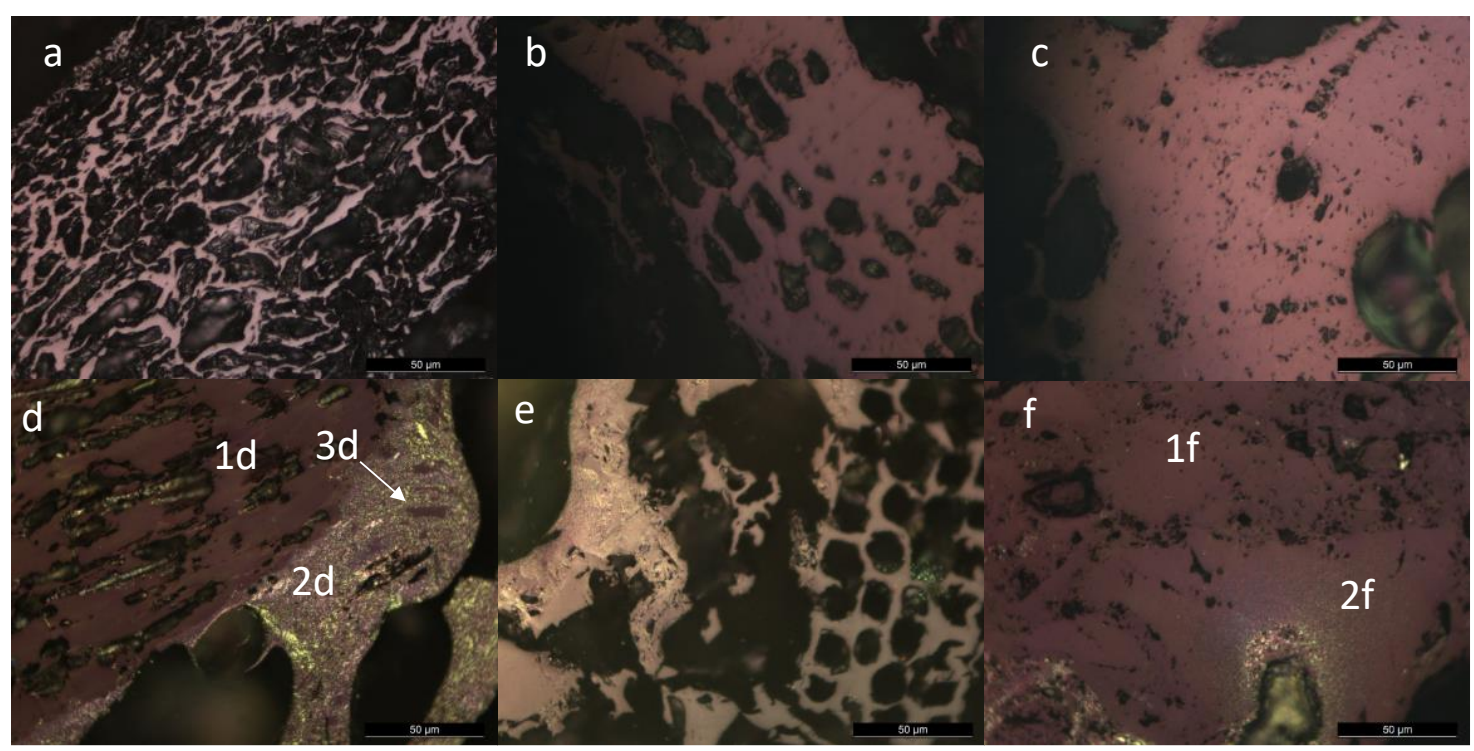

426 Figure 6. Polarized optical microscopy images of chars obtained from BIOC (a), SP (b) 427 and $\mathrm{Lg}(\mathrm{c})$ and cokes from $\mathrm{Br}(\mathrm{BIOC}-\mathrm{Mol})(\mathrm{d}), \mathrm{Br}$ (SP-T/CTS) (e) and $\mathrm{Br}$ (Lg-T/CTS) (f). 


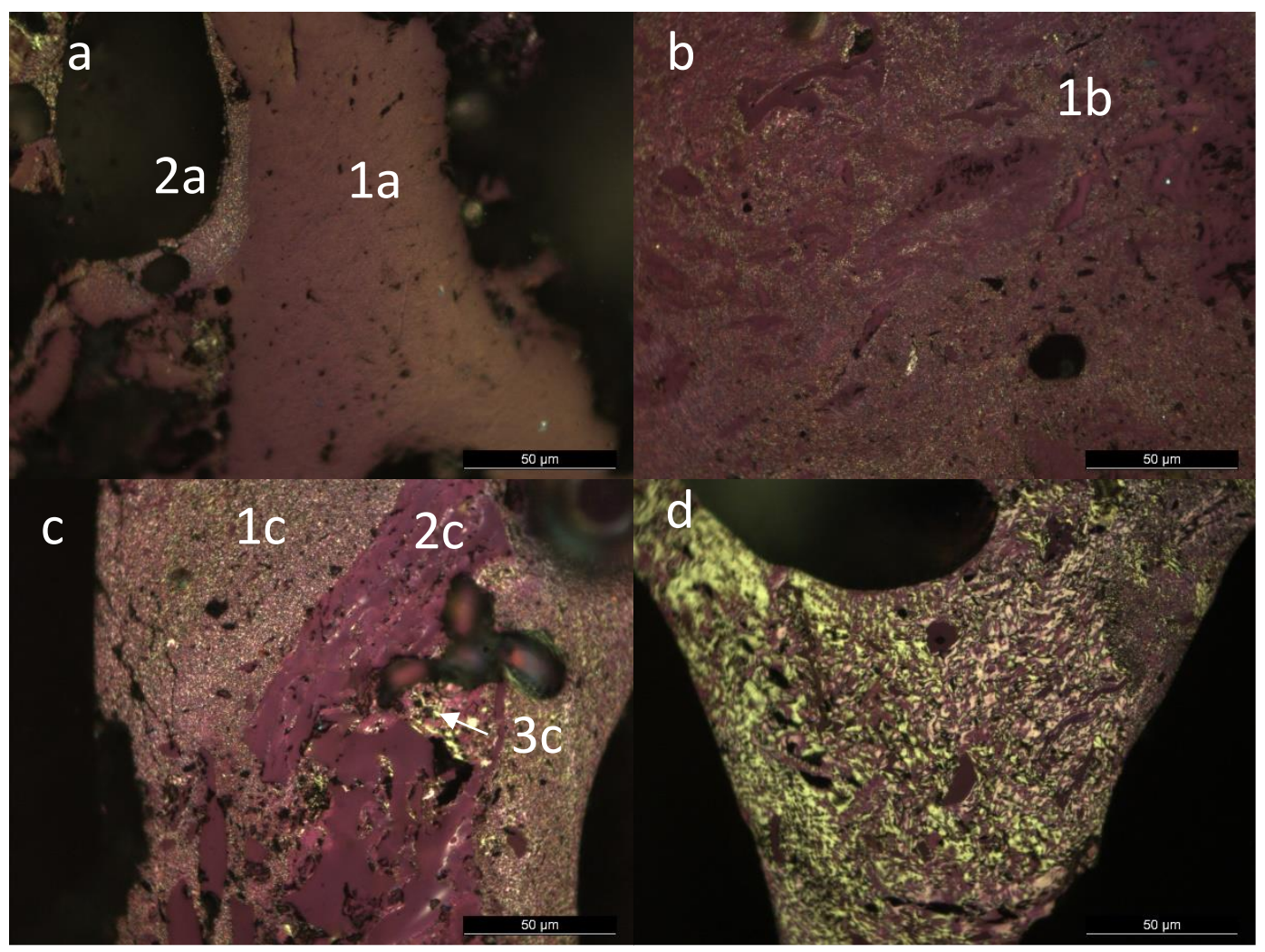

Figure 7. Polarized optical microscopy images of cokes obtained from $\mathrm{Br}(\mathrm{Mol})(\mathrm{a})$, $\operatorname{Br}(\operatorname{Par})(\mathrm{b}), \operatorname{Br}(\mathrm{T} / \mathrm{CTS})(\mathrm{c})$ and $\operatorname{Br}(\mathrm{T})(\mathrm{d})$. which is a consequence of the rank of the coal present in their composition. It is considered that for a coal of $31.5 \mathrm{wt} \% \mathrm{db}$, fine mosaic units, formed from the isotropic matrix generated during the softening of the coal mass, either retain their identity or act as intermediaries in the formation of larger mosaic entities [38]. The flow component present in the coke briquettes is mainly of the granular flow type. The formation of granular flow components occurs as a result of the progressive coalescence of initially formed mosaic units. Sufficient fluidity is essential for this process [39]. Molasses has a deleterious effect on the fluidity of the coal and impedes the coalescence and growth of fine grained mosaics. This effect is also accompanied by an increase in the amount of isotropic components (Table 7). On the other hand, tar and the 1:1 blend T/CTS produce an increase in fluidity which favors the presence of larger size textural 
components i.e. the flow type. The biomass (i.e. BIOC and sawdust) produces a 447 decrease in anisotropic components and an increase in the percentage of inerts [2] 448 (Table 7).

449 Coke exhibits a variety of microscopic textures, whose optical appearance under 450 polarized light helps to explain the relationship between microtexture and strength [40].

451 In the present research work, the $\mathrm{R}_{3}$ index is directly related to the amount of mosaics $452\left(r^{2}=0.648\right)$ and inversely related to the amount of large inerts $\left(r^{2}=0.781\right)$ (Figure 8). 453 Although the correlation coefficients are not very high and other factors may have an 454 influence, it is clear that coke strength is favored by a high percentage of mosaics and 455 a low percentage of large inerts. Small inerts do not seem to be related to the $\mathrm{R}_{3}$ index $456\left(r^{2}=0.064\right)$, because they are more integrated within the coke matrix and have 457 interfaces of a higher quality with the surrounding structure $[13,36]$.

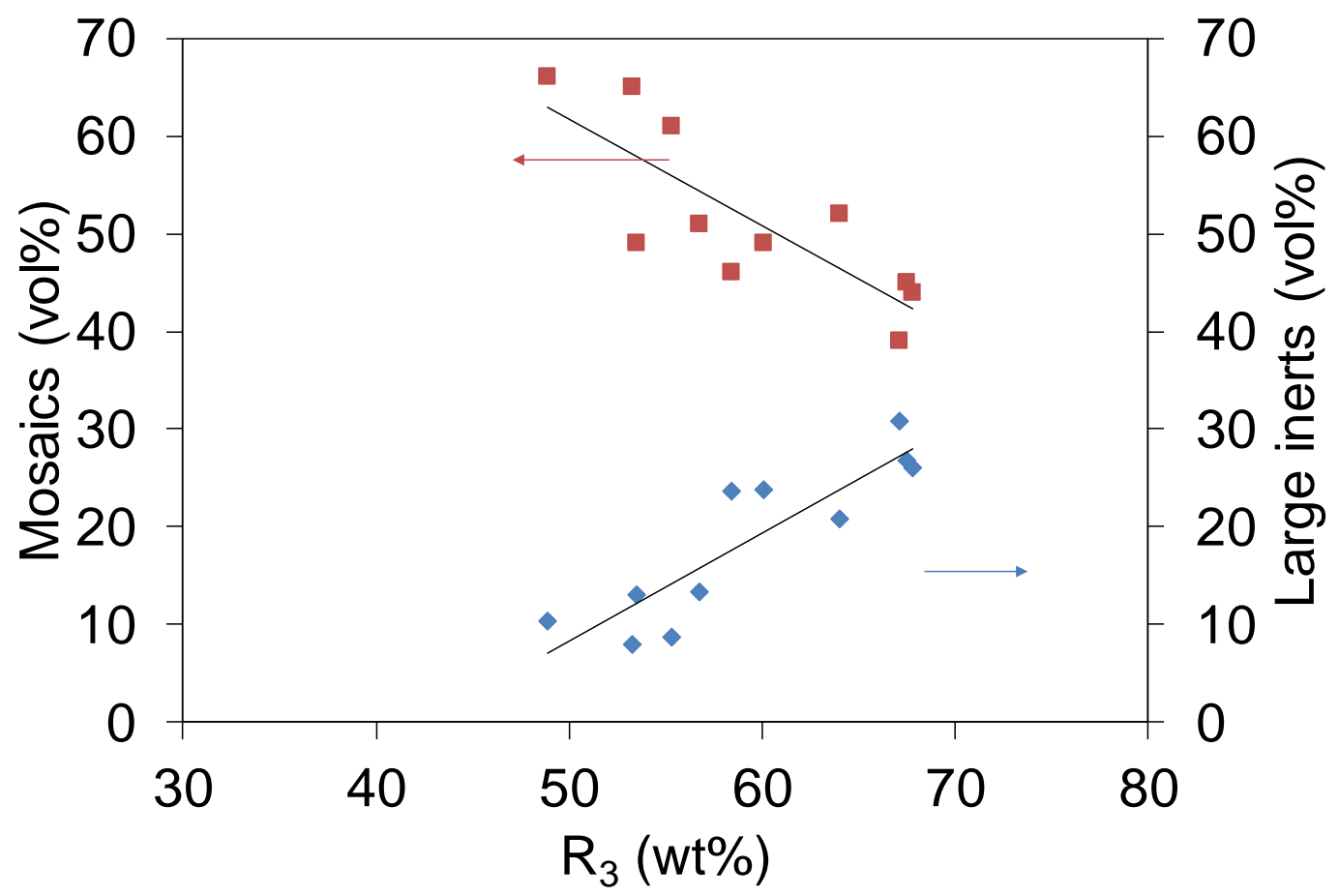

Figure 8. Relationship between the PLM textural composition and the $\mathrm{R}_{3}$ index. 
The effect of four binders and four biomasses on the strength of cokes prepared from briquettes has been studied. The following order has been established for the binders: T/CTS $>$ T $>$ Molasses $>$ Paraffin. Bituminous binders are the most effective because they increase Gieseler fluidity and have a lower volatile matter content than molasses and paraffin. Briquettes prepared with paraffin produce cokes with a lower strength than molasses. The most likely reason for this is their high volatile matter content because molasses produces a sharp decrease in anisotropy. $\mathrm{BIOC}>\mathrm{SP}>\mathrm{SPT}$. This is because $\mathrm{Lg}$ and BIOC produce the briquettes that have the highest density and at the same time the lowest percentage of macropores in the coke. In addition, Lg agglomerates during heating which favours its integration within the coke matrix. The combination of lignin with bituminous binders produces the best compression strength results. The combination lignin/molasses is the best without a bituminous binder. High percentage of mosaics and low of inerts favours coke mechanical strength.

Acknowledgements

The research leading to these results has received funding from the European Union's

482 Research Fund for Coal and Steel (RFCS) research program under grant agreements

483 No. [RFCR-CT-2014-00006] and No [RFCS-CT-2010-00006].

\section{References}

485 [1] Mousa E, Wang C, Riesbeck J, Larsson M. Biomass applications in iron and 486 steel industry: An overview of challenges and opportunities. Renew Sustain Energy 487 Rev 2016;65:1247-66. doi:10.1016/j.rser.2016.07.061.

488 [2] Montiano MG, Díaz-Faes E, Barriocanal C, Alvarez R. Influence of biomass on 489 metallurgical coke quality. Fuel 2014;116:175-82. doi:10.1016/j.fuel.2013.07.070.

490 [3] Matsumura T, Ichida M, Nagasaka T, Kato K. Carbonization behaviour of woody 491 biomass and resulting metallurgical coke properties. ISIJ Int 2008;48:572-7.

492 doi:10.2355/isijinternational.48.572. 
[4] $\quad \mathrm{Ng} \mathrm{KW,} \mathrm{MacPhee} \mathrm{JA,} \mathrm{Giroux} \mathrm{L,} \mathrm{Todoschuk} \mathrm{T.} \mathrm{Reactivity} \mathrm{of} \mathrm{bio-coke} \mathrm{with} \mathrm{CO2.}$ Fuel Process Technol 2011;92:801-4. doi:10.1016/j.fuproc.2010.08.005.

495 [5] Kudo S, Mori A, Soejima R, Murayama F, Karnowo, Nomura S, et al. 496 Preparation of Coke from Hydrothermally Treated Biomass in Sequence of Hot 497 Briquetting and Carbonization. ISIJ Int 2014;54:2461-9.

498 doi:10.2355/isijinternational.54.2461.

499 [6] Florentino-Madiedo L, Díaz-Faes E, García R, Barriocanal C. Influence of 500 binder type on greenhouse gases and PAHs from the pyrolysis of biomass briquettes.

501 Fuel Process Technol 2018;171:330-8. doi:10.1016/j.fuproc.2017.11.029.

502 [7] Loison R, Foch P, Boyer A. 4 - Coke quality criteria. Coke, Butterworth503 Heinemann; 1989, p. 158-200. doi:10.1016/B978-0-408-02870-7.50009-2.

504 [8] Ananthanarayanan PS, Balachandran G, Balasubramanian N, Battle T, Birat J505 P, Blanpain B, et al. Contributors to Volume 3. In: Seetharaman S, editor. Treatise 506 Process Metall., Boston: Elsevier; 2014, doi:10.1016/B978-0-08-096988-6.09987-9.

507 [9] Mochizuki Y, Naganuma R, Tsubouchi N. Influence of Inherently Present 508 Oxygen-Functional Groups on Coal Fluidity and Coke Strength. Energy Fuels 509 2018;32:1657-64. doi:10.1021/acs.energyfuels.7b03774.

510 [10] Ueki Y, Nunome Y, Yoshiie R, Naruse I, Nishibata Y, Aizawa S. Effect of Woody 511 Biomass Addition on Coke Properties. ISIJ Int 2014;54:2454-60.

512 doi:10.2355/isijinternational.54.2454.

513 [11] Montiano MG, Díaz-Faes E, Barriocanal C. Partial briquetting vs direct addition 514 of biomass in coking blends. Fuel 2014;137:313-20. doi:10.1016/j.fuel.2014.08.012.

515 [12] Qiu S, Zhang S, Zhu R, Wu Y, Qiu G, Dang J, et al. Influence of TiO2 addition 516 on the structure and metallurgical properties of coke. Int J Coal Prep Util 2018:1-17. 517 doi:10.1080/19392699.2018.1496913.

518 [13] Barriocanal C, Hanson S, Patrick JW, Walker A. The characterization of 519 interfaces between textural components in metallurgical cokes. Fuel 1994;73:1842-7. 520 doi:10.1016/0016-2361(94)90209-7.

521 [14] Sharma AK, Das BP, Tripathi PSM. Influence of properties of bituminous 522 binders on the strength of formed coke. Fuel Process Technol 2002;75:201-14. 523 doi:10.1016/S0378-3820(01)00257-0.

524 [15] Florentino-Madiedo L, Díaz-Faes E, Barriocanal C, Castro-Díaz M, Snape CE. 525 Importance of Biomass and Binder Selection for Coking Briquette Preparation. Their 526 Effect on Coal Thermoplastic Properties. Energy Fuels 2018.

527 doi:10.1021/acs.energyfuels.8b02555.

528 [16] Díaz-Faes E, Barriocanal C, Díez MA, Alvarez R. Characterization of different 529 origin coking coals and their blends by Gieseler plasticity and TGA. J Anal Appl 530 Pyrolysis 2007;80:203-8. doi:10.1016/j.jaap.2007.02.008. 
531 [17] Ragan S, Marsh H. Carbonization and liquid-crystal (mesophase) development. 532 22. Micro-strength and optical textures of cokes from coal-pitch co-carbonizations. Fuel 1981;60:522-8. doi:10.1016/0016-2361(81)90116-2.

534 [18] Riley H. Coke Oven Manag Year-Book 1940:312.

535 [19] Amanat N, Tsafnat N, Loo BCE, Jones AS. Metallurgical coke: An investigation 536 into compression properties and microstructure using X-ray microtomography. Scr 537 Mater 2009;60:92-5. doi:10.1016/j.scriptamat.2008.09.003.

538 [20] Patrick JW, Reynolds MJ, Shaw FH. Development of optical anisotropy in 539 vitrains during carbonization. Fuel 1973;52:198-204. doi:10.1016/0016540 2361(73)90079-3.

541 [21] Lumadue MR, Cannon FS, Brown NR. Lignin as both fuel and fusing binder in 542 briquetted anthracite fines for foundry coke substitute. Fuel 2012;97:869-75. 543 doi:10.1016/j.fuel.2012.02.061.

544 [22] Peña L, Mitchell G, Cannon FS, Komarneni S, Brown NR. The pyrolytic 545 evolution of morphology in biobased coke replacement briquettes: Links between 546 morphology, nanowire characteristics, and performance in cupolas. Carbon 547 2018;140:458-64. doi:10.1016/j.carbon.2018.08.046.

548 [23] Castro-Díaz M, Uguna CN, Florentino L, Díaz-Faes E, Stevens LA, Barriocanal $549 \mathrm{C}$, et al. Evaluation of hydrochars from lignin hydrous pyrolysis to produce biocokes 550 after carbonization. J Anal Appl Pyrolysis 2017;124:742-51.

551 doi:10.1016/j.jaap.2016.11.010.

552 [24] Alvarez R, Barriocanal C, Díez MA, Cimadevilla JLG, Casal MD, Canga CS. 553 Recycling of Hazardous Waste Materials in the Coking Process. Environ Sci Technol 554 2004;38:1611-5. doi:10.1021/es030077y.

555 [25] Hannu Suopajärvi, Essi Dahl, Antti Kemppainen, Stanislav Gornostayev, Aki 556 Koskela, Timo Fabritius. Effect of Charcoal and Kraft-Lignin Addition on Coke 557 Compression Strength and Reactivity. Energies n.d.;10:1850-65.

558 [26] Loison R, Foch P, Boyer A. Coke: Quality and Production. London: Elsevier; 5591989.

560 [27] Melendi S, Diez MA, Alvarez R, Barriocanal C. Relevance of the composition of 561 municipal plastic wastes for metallurgical coke production. Fuel 2011;90:1431-8. 562 doi:10.1016/j.fuel.2011.01.011.

563 [28] Fernández AM, Barriocanal C, Díez MA, Alvarez R. Importance of the textural 564 characteristics of inert additives in the reduction of coal thermoplastic properties. Fuel 565 2010;89:3388-92. doi:10.1016/j.fuel.2010.03.006.

566 [29] North L, Blackmore K, Nesbitt K, Mahoney MR. Models of coke quality 567 prediction and the relationships to input variables: A review. Fuel 2018;219:446-66. 568 doi:10.1016/j.fuel.2018.01.062. 
569 [30] Wei J, Zhou M, Wei X, He G, Song L, Lei J. Prediction of coke strength using 570 linear regression method. China Coal 2011;6:0-24.

571 [31] Zheng A, Jiang L, Zhao Z, Huang Z, Zhao K, Wei G, et al. Impact of 572 Torrefaction on the Chemical Structure and Catalytic Fast Pyrolysis Behavior of 573 Hemicellulose, Lignin, and Cellulose. Energy Fuels 2015;29:8027-34.

574 doi:10.1021/acs.energyfuels.5b01765.

575 [32] Patrick JW, Stacey AE. The strength of industrial cokes. 7. Further studies of 576 the influence of additives in a coke-oven charge on the tensile strength of coke. Fuel 577 1978;57:258-64. doi:10.1016/0016-2361(78)90001-7.

578 [33] Matsumura T, Ichida M, Nagasaka T, Kato K. Carbonization Behaviour of 579 Woody Biomass and Resulting Metallurgical Coke Properties. ISIJ Int 2008;48:572-7. 580 doi:10.2355/isijinternational.48.572.

581 [34] Montiano MG, Díaz-Faes E, Barriocanal C. Effect of briquette composition and 582 size on the quality of the resulting coke. Fuel Process Technol 2016;148:155-62. 583 doi:10.1016/j.fuproc.2016.02.039.

584 [35] Sato H, Patrick JW, Walker A. Effect of coal properties and porous structure on 585 tensile strength of metallurgical coke. Fuel 1998;77:1203-8. doi:10.1016/S0016586 2361(98)00019-2.

587 [36] Barriocanal C, Hanson S, Patrick JW, Walker A. Reactive-inert interfaces in 588 metallurgical cokes: effect of added inerts. Fuel 1996;75:243-5. doi:10.1016/0016589 2361(95)00233-2.

590 [37] Marsh H, E. Clarke D. MECHANISMS OF FORMATION OF STRUCTURE 591 WITHIN METALLURGICAL COKE AND ITS EFFECT ON COKE PROPERTIES. vol. $59239,1986$.

593 [38] Patrick JW, Reynolds MJ, Walker A. Coal carbonization and coke anisotropy: 594 some comments. Fuel 1983;62:131-2. doi:10.1016/0016-2361(83)90269-7.

595 [39] Moreland A, Patrick JW, Walker A. Optical anisotropy in cokes from high-rank 596 coals. Fuel 1988;67:730-2. doi:10.1016/0016-2361(88)90307-9.

597 [40] SHARMA R, DASH PS, BANERJEE PK, KUMAR D. Effect of Coke Micro598 Textural and Coal Petrographic Properties on Coke Strength Characteristics. ISIJ Int $5992005 ; 45: 1820-7$. doi:10.2355/isijinternational.45.1820. 